\title{
INFLUENCE OF SELENIUM ON OXIDATIVE STRESS IN ATHLETES. REVIEW ARTICLE
}

\author{
Krzysztof Sieja, , A, B, D Joanna von Mach-Szczypińska, 2, A, B, C, E Natalia Kois, 3, B, C \\ Paulina Ler, ${ }^{3, B, C}$ Klaudia Piechanowska, ${ }^{3, B, C}$ Michalina Stolarska ${ }^{3, B, C}$ \\ ${ }^{1}$ Faculty of Physical Culture and Health Promotion, University of Szczecin, Poland \\ 2 Sant Joseph Krankenhaus, Berlin, Germany \\ ${ }^{3}$ Students, Faculty of Physical Culture and Health Promotion, University of Szczecin, Poland \\ A Study Design; ${ }^{\text {B }}$ Data Collection; ${ }^{\mathrm{C}}$ Statistical Analysis; ${ }^{\mathrm{D}}$ Manuscript Preparation; ${ }^{\mathrm{E}}$ Funds Collection
}

\author{
Address for corpespondence: \\ Krzysztof Sieja, MD \\ University of Szczecin, Faculty of Physical Culture and Health Promotion \\ Al. Piastów 40b, building 6, 71-065 Szczecin, Poland \\ E-mail:siejakrzysztof@wp.pl
}

\begin{abstract}
Ahstract. The aim of the study was to analyze the influence of selenium (Se) on the course of oxidative stress in trained athletes, on the basis of own former published studies and the reference of literature. In a number of references it was shown that the application of Se led to the diminishing of oxidative stress during the physical exercises in athletes. The application of Se to athletes - led to the increase of peroxidase glutathione the main selen - dependent enzyme. The fact of increased concentration of malondialdehyde (MDA) in blood serum, the main metabolite of lipid peroxidation can indirectly evidence about the intensity of physical endurance. This increase is significantly smaller in individuals taking exogenous antioxidative diet supplement containing Se. Moreover there is the evidence that oxidative muscles damage during physical effort could be diminished by compounds with antioxidative properties. Taking into consideration, the obtained results by many of authors empower to the conclusion that application of Se diminishes the degree of peroxidation of lipids in trained athletes.
\end{abstract}

Key Worlls: selenium, gluthatione peroxidase, malondialdehyde, athletes, physical exercise

\section{Introduction}

Due to its significant biological functions, as well as slight diversity between the dose essential for proper functioning of the organism and its toxic dosage, during recent years selenium concentration constituted a subject of considerable interest as far as toxicology specialists and researchers from other branches are concerned (Sieja,Talerczyk, 2004; Zyska, Ślęzak, 2007; Puzanowska-Tarasiewicz, Kuźnicka, Tarasiewicz, 2009; Lippman et al., 2011).

Until now it has been documented that the strained physical exercise causes the increased production of free radicals. This process brings into the changes of oxidative state of the cells during short-term effort, as well as in 
long-term adaptation to physical exercises. (Savory et al., 2012; Kaczmarski, Wójcicki, Samochowiec, Dutkiewicz, Sych, 1999).

The aim of this study is the presentation of the influence of selenium (Se) on the cause of oxidative stress in athletes on the basis of review.

Depending on the quantity of Se given there are changes of gluthatione peroxidase. This enzyme is increasing with the increase of Se ingestion (Rokitzki, Logemann, Keul, 1993). Besides this, Se is incorporated into other compounds having significance in the antioxidative processes such as selenocysteine and selenomethionine. It was shown that the increase in the amount of ingested Se leads to the increase of synthesis of biological active compounds containing Se, which assures peroxidation of lipids caused by free radicals (Sieja, Talerczyk, 2004; Drozda, Trzciński, Rutkowski,Grzegorczyj, 2008).

The most of reports as safe and adequate for people consider the doses of this microelement recommended by The Food and Nutrition Board of the National Research Council proposed in 1980 amounted to from 50 to 200 $\mu \mathrm{g}$ per day (Table 1).

Table 1. Safe and adequate amounts of Se ingested in diet (according to: National Research Council: Recommended dietary allowances 9 th revised ed., Washington D.C. Natl. Acad. Sci., 1980)

\begin{tabular}{lcc}
\cline { 2 - 2 } & Age $(\mathrm{y})$. & $\begin{array}{c}\text { Recommended amount of ingested Se } \\
(\mu \mathrm{g} / \text { per day })\end{array}$ \\
\hline \multirow{2}{*}{ Infants } & $0.0-0.5$ & $10-40$ \\
& $0.5-1.0$ & $20-60$ \\
\hline \multirow{3}{*}{ Children } & $1-3$ & $20-80$ \\
& $4-6$ & $30-120$ \\
& $7-11$ & $50-200$ \\
\hline Adults & & $50-200$ \\
\hline
\end{tabular}

\section{Discussion}

According to Dróżdż, Tomala, Jędryczka (1989) the normal concentration of Se in blood serum of adult in Poland should be $125 \pm 18 \mathrm{ng} / \mathrm{mL}$. In Table 2 the concentrations of Se in blood serum in adults in Poland according to different authors are presented (Wąsowicz, Gromadzińska, Rydzyński, 2003; Łabędzka, 1991; Zachara, Wąsowicz, Gromadzińska, 1995; Kłapcińska, Poprzecki, Danch, 2005; Kapka, Baumgartner, Siwińska, 2007). As it results from this table this concentration is below the optimal value (Gać, Pawlas, 2011).

Table 2. The concentration of Se in blood serum in healthy adult persons in Poland according to different authors

\begin{tabular}{lcl}
\hline \multicolumn{1}{c}{ Region of Poland } & $\begin{array}{c}\text { The concentration of Se in blood serum } \\
(\mathrm{ng} / \mathrm{mL})\end{array}$ & \multicolumn{1}{c}{ Authors } \\
\hline Pomerania & $73.7 \pm 15.4$ & Łabędzka, 1991 \\
Pomerania & 52.0 & Zachara et al., 1985 \\
District of Łódź & $50.0-55.0$ & Wasowicz et al., 2003 \\
Upper Silesia & $63.5 \pm 18.1$ & Kłapcińska et al., 2005 \\
District of Lublin & $51.0 \pm 8.26$ & Kapka et al., 2007 \\
\hline
\end{tabular}


The other antioxidant taking part in the protection of cells from free radicals is vitamin $\mathrm{E}$. It was shown that oxidative damage of many tissues is greater in the case of deficiency of both of these compounds. Lee, Csalhany (1994), Kaczmarski et al. (1999) gave young men diet supplement Protecton Zell Activ (Smith Kline Beecham) containing in one capsule Se $(25 \mu \mathrm{g})$ and vitamin $\mathrm{E}(18 \mathrm{mg})$, and moreover $100 \mathrm{mg}$ vitamin C, $22 \mathrm{mg}$ niacini, $7.5 \mathrm{mg}$ $\beta$-caroten and $2.25 \mathrm{mg}$ witamine $\mathrm{B}_{2}$ two-times per day orally after eating for one month. Before and after the physical exercises during one month the concentration of $\mathrm{Se}$ in blood serum was determined.

The application of the above-mentioned drug caused significant increase of Se concentration in serum from $55.55 \pm 21.62$ to $92.60 \pm 11.61 \mu \mathrm{g} / \mathrm{dl}$ ( $p<0.001$ ). The muscles condition was monitored by the activity of lactate dehydrogenase and creatinie kinase in serum. Simultaneously significant decrease of activity of lactate dehydrogenase and creatinine kinase was found. Davies, Qintanilha, Brooks, Packer (1982) revealed that the intense physical exercise very often causes the damage of muscle and the loss of their normal activity. Thus, it can contributed to damaging action of free radicals. In the course of physical effort excessive peroxidation of lipids took place (Viguie et al., 1993; Rokitzki et al., 1993).

The comparison of the activity phosphocreatinie kinase in rest before and after the therapy with „Protecton Zell Activ" revealed significant decrease of this activity following taking this drug. The above-mentioned diet supplement could probably have favourable influence on the metabolism of muscle tissue, thus causing the decrease in resting concentration of phosphocreatine kinase in serum.

The fact of increased concentration of malondialdehyde (MDA) in blood serum, the main metabolite of lipid peroxidation can indirectly evidence about the intensity of physical endurance.This increase is significantly smaller in individuals taking above-mentioned exogenous antioxidative diet supplement.

It proved the protective influence of Se on lipid peroxidation and thus on its antioxidative effect (Łabędzka 1991). Davies, Qintanilha, Brooks, Packer L. (1982), Kaczmarski et al. (1999) and Clarkson, Thomson (2000) have shown that physical endurance increases the concentration of free radicals and the quantity of arising malondialdehyde (MDA). A number of authors have shown that with the degree of intensification of physical strength the concentration of MDA in overstretched muscles increases. However, the increase of training is the cause of diminishing concentration of MDA in blood serum (Alessio, Goldfarb, Cutler, 1988; Kaczmarski et al., 1999; Rokitzki et al., 1993). Kaczmarski et al. (1999) studies revealed that the application of medication „Protecton Zell Activ” - diet supplement - which main compound was Se, led to diminishing oxidative stress, not only in the course of physical effort but simultaneously it was the cause of diminishing of the grade of lipid peroxidation - during long-term application in healthy individuals. Moreover, the study of Sieja, Talerczyk (2004) has also shown the decreasing of oxidative stress after the application of the above-mentioned diet supplement in women with ovarian cancer undergoing chemotherapy. Selenium and zinc supplementation may improve general clinical course in patients with cancer of digestive tract (Federico, Lodice, Derl Rio, Mellone, 2001; Wojtczak, 2003).

The increase of malondialdehyde (MDA) indirectly indicate about oxidative status evoked by physical exercise. The application of Se during training causes the significant increase of glutathione peroxidase activity and hence the increase of antioxidative barriers (Kaczmarski et al., 1999; Savory et al., 2012; Clarkson, Thompson, 2000). Antioxidants such as Se, vitamin $\mathrm{E}$, vitamin $\mathrm{C}$ in trained individuals favourably affect free radicals metabolism determined by the concentration of malondialdehyde (MDA) in blood serum. The application of "Protecton Zell Active" diet supplement led to the increase of antioxidative potential of the organism determined by the concentration of malondialdehyde (MDA) in blood serum. (Kaczmarski, 1998). 
One month application of "Protecton Zell Aktiv" - diet supplement - caused significant increase of Se concentration in blood serum. It must be underlined that after discontinuation of this diet supplement, after the period of one month the concentration of Se is lowering to values similar to these observed before the application of Se (Sieja, Talerczyk, 2004).

The above-mentioned clinical results were affirmed by experimental results on rats. The results of study of Akil et al. (2015) indicate that acute swimming exercises in rats cause lipid peroxidation in liver and lung tissues while Se administration prevents free radical formation by increasing antioxidant activity.

Savoy et al. (2012) have shown that both obesity, as well as acute high-intensity exercise increase oxidant stress levels, the study of the above-mentioned authors revealed that Se supplementation could be a potentially effective therapy to reduce obesity-associated oxidant stress and exercise-induced oxidant stress. This study has highlighted a potential benefit of Se in reducing LH (lipid peroxide) levels postexercise in overweight individuals. Given that oxidant stress is a predictor of coronary events, it is imperative to better understand oxidant-related responses to life-style (in particular in "high-risk" population groups) and potential antioxidant therapy (Fredrikson et al., 2004).

Physical exercises appear to increase reactive forms of oxygen, which could led to damage of the cells. Physical exercises lead to the increase of MDA concentration in blood serum. The concentration of MDA serves as indirect index of lipid peroxidation (Carkson,Thompson, 2000). Physical training seems to reduce oxidative stress of exercises. Trained athletes who received antioxidant supplements show evidence of reduced oxidative stress and increase of immune defence system compared to untrained individuals (Clarkson, Thompson, 2000; Döker et al., 2014).

Currently, more and more convincing evidence that oxidative muscles damage during physical effort could be diminished by compounds with antioxidative properties has been obtained. Theoretically, systematically trained physical exercise could demand adequate antioxidant supplementation. Until now the results of studies fully confirm that long-time application of antioxidants is safe and effective. Thoughtful recommendation for physically active individuals is consuming diet rich in antioxidants including Se (Fredrickson et al., 2004; Margarits et al., 2005).

Trained athletes who obtain antioxidants reduced oxidative stress (Margaritis et al., 2005). On this basis many of trained athletes are taking diet supplements with antioxidative compounds. Until now the influence of antioxidants on physical effort induced by oxidative stress in individuals undertaking sporadically intensive physical exercise is not fully explained. Pograjc, Stibilj, Falnoga (2012) did not found favourable influence of exogenous antioxidants in the course of oxidative stress evoking short-term physical effort in untrained individuals.

Taking into consideration the results obtained by many of the authors (Akil et al., 2015; Lee, Csalhany, 1994; Margarits et al., 2005; Kaczmarski, 1999; Sieja, Talerczyk, 2004) we are empowered to the conclusion that application of Se diminishes the degree of peroxidation of lipids in trained athletes.

\section{Conclusions}

1. Application of selenium diminishes the degree of peroxidation of lipids in trained athletes.

2. Long-time application of antioxidants is safe and effective. 


\section{References}

Akil, M., Gurbuz, U., Bicer, M., Halifeoglu, I., Baltaci, A.K., Mogulkoc, R. (2015). Selenium prevents lipid peroxidation in liver and lung tissues of rats in acute swimming exercise. Bratisl. Lek. Listy, 116 (4), 233-235.

Alessio, H.M., Goldfarb, H., Cutler, R.G. (1988). MDA content increases in fast and slow - switch skeletal muscle with intensity of exercise in rat. Amer. J. Physiol., 25, C874-877.

Clarkson, P.M., Thompson, H.S. (2000). Antioxidants; what role do they play in physical activity and health?. Amer. J. Clin. Nutr., 72 (2 Suppl.), 637S-646S.

Davies, K.J.A., Qintanilha, A.T., Brooks, G.A., Packer, L. (1982). Free radicals and tissue damage produced by exercise. Biochem. Biophys. Res. Comm., 107, 1198-1205.

Döker, S., Hazar, M., Uslu, M., Okan, I., Kafkas, E., Bosgelmez, Ł. (2014). Influence of training frequency on serum concentrations of some essential trace elements and electrolytes in male swimmers. Biol. Trace Elem Res., 158 (1), 15-21.

Drozda, R., Trzciński, R., Rutkowski, M., Grzegorczyj, K. (2008). Stężenia antyoksydacyjnych pierwiastków śladowych - selenu i cynku - u chorych z rakiem esicy lub odbytnicy. Gastroenterol. Pol., 15 (6), 391-395.

Dróżdż, M., Tomala, J., Jędryczka, A. (1989). Concentration of selenium and vitamin $\mathrm{E}$ in the serum of women with maligant genital neoplasms and their family members. Polish. Gynecology (Polish), 60, 301-305.

Federico, A., Lodice, P., Derl Rio, A., Mellone, M. (2001). Effects of selenium and zinc supplementation on nutrition status in patients with cancer of digestive tract. Eur. J. Clin. Nutr., 55, 293-297.

Fredrikson, G.N., Hedblad, B., Nilsson, J.A., Alm, R., Berglund, G., Nilsson, J. (2004). Association between diet, lifestyle, metabolic cardiovascular risk factors, and plasma C-Reactive protein levels. Metabolism, 53 (11), 1436-1442.

Gać, P., Pawlas, K. (2011). Stężenie selenu we krwi w różnych populacjach osób zdrowych i chorych - przegląd piśmiennictwa z lat 2005-2011. Medycyna Środowiskowa, 14 (1), 93-104.

Kaczmarski, M. (1998). Wpływ egzogennych przeciwutleniaczy na powstawanie stresu oksydacyjnego w czasie wysiłku fizycznego PhD thesis (pp. 1-50). Szczecin: Pomorska Akademia Medyczna.

Kaczmarski, M., Wójcicki, J., Samochowiec, L., Dutkiewicz, T., Sych, Z. (1999). Influence of exogenous antioxidants and physical exercise on some parameters associated with production and removal of free radicals. Pharmazie, 54 (4), 303-306.

Kapka, L., Baumgartner, A., Siwińska, E. (2007). Environmental lead exposure increases micronuclei in children. Mutagenesis, 22, 201-207.

Kłapcińska, B., Poprzecki, S., Danch, A. (2005). Selenium levels in blood of upper Silesian population: evidence of suboptimal selenium satus in a significant percentage of the population. Biol. Trace Elem. Res., 108, 1-15.

Lee, H.S., Csalhany, A.S. (1994). The influence of Vitamin E and Se on lipid peroxidation and aldehyd dehydrogenase activity in rat liver and tissue. Lipids, 29, 345-350.

Lippman, S.M., Klein, E.A., Goodman, P.J., Lucia, M.S., Thompson, I.M., Ford, L.G, Parnes, H.L, Minasian, L.M. et al. (2009). Effect of selenium and vitamin $\mathrm{E}$ on risk of prostate cancer and other cancers. The selenium and vitamin $\mathrm{E}$ cancer prevention trial (SELECT). JAMA, 301 (1), 39-51.

Łabędzka, H. (1991). Wpływ podaży różnych preparatów selenu na stężenie oraz aktywność peroksydazy glutationowej we krwi osób zdrowych - PhD thesis. Bydgoszcz: Akademia Medyczna w Bydgoszczy.

Margaritis, I., Rousseau, A-S., Hininger, I., Palazzetti, S., Arnaud, J., Roussel, A.-M. (2005). Increase in selenium requirements with physical activity loads in well-trained athletes is not linear. Biofactors, 23 (1), 45-55.

Pograjc, L., Stibilj, V., Falnoga, I. (2012). Impact of intensive physical activity on selenium status. Biol. Trace Elem. Res., 145 (3) 291-299.

Puzanowska-Tarasiewicz, H., Kuźmicka, L., Tarasiewicz, M. (2009). Funkcje biologiczne pierwiastków i ich związków. II. Selen, seleniany, związki selenoorgancizne. Pol. Merk. Lek., 27 (259), 249-252.

Rokitzki, L., Logemann, E., Keul,J. (1993). Selenium metabolism and glutathione activity of endurance athletes in rest and under exertion. Schweiz. Z. Sportmed., 41 (1), 21-27.

Savory, L.A., Kerr, C.J., Whiting, P., Finer, N., Mc Eneny, J., Ashton T. (2012). Selenium supplementation and exercise: effect on oxidant stress in overweight adults. Obesity, 20 (4), 794-801.

Sieja, K., Talerczyk, M. (2004). Selenium as an element in the treatment of ovarian cancer in women receiving chemotherapy. Gynecologic Oncology, 93, 320-327. 
Wąsowicz, W., Gromadzińska, J., Rydzyński, K. (2003). Selenium status of low selenium area residents. Polish experience. Toxicol. Lett., 37 (1-2), 95-101.

Viguie, C.A., Frei, B., Shigenaga, M.K., Ames, B.N., Packer, L., Brooks, G.A. (1993). Antioxidant status and indexes of oxidative stress during consecutive days of exercise. J. App. Physiol., 745, 566-572.

Wojtczak, A. (2003). Selenium as an anticancerogenic agent. Acta Poloniae Pharmaceutica - Drug Research, 60 (3): $215-217$.

Zachara, B., Wąsowicz, W., Gromadzińska, J. (1985). Glutathione peroxidase activity, selenium and lipid peroxide concentrations in blood from healthy Polish population. Histol. Trace Elem. Res., 10, 175-182.

Zyska, A., Ślęzak, A. (2007). Rola genów i diety w modyfikowaniu ryzyka zachorowania na raka jelita grubego. Żywienie Czlowieka, 34 (6), 1640-1647.

Cite this article aS: Sieja, K., Mach-Szczypińska, J., Kois, N., Ler, P., Piechanowska, K., Stolarska, M. (2016). Influence of Selenium on Oxidative Stress in Athletes. Review Article. Central European Journal of Sport Sciences and Medicine, 14 (2), 87-92. DOI: 10.18276/ cej.2016.2-10. 